\title{
Specifics of Labor Market of Monotowns in the Republic of Kazakhstan
}

\author{
Amanbekov Nurzhan ${ }^{1}$ \\ ${ }^{1}$ L. N. Gumilyov Eurasian National University, Kazakhstan \\ Correspondence: Amanbekov Nurzhan, Mirzoyana Str., 2, Astana, 010008, Kazakhstan. E-mail: \\ nuraman83@mail.ru
}

Received: February 3, 2015 Accepted: April 28, 2015 Online Published: July 30, 2015

doi:10.5539/ass.v11n19p257 URL: http://dx.doi.org/10.5539/ass.v11n19p257

\begin{abstract}
The article deals with the problems of labor market in factory towns or monotowns in the Republic of Kazakhstan. Main components, structure and relations in labor market of monotown have been reviewed. The effect of forming a factory town enterprise on labor market and social and economic development of such towns in general has been analyzed. Attempt has been made to analyze problems of a monotown; factors that have negative effect on economic growth of monotown were revealed. One of possible ways of solving the problem of monotowns by forming urban agglomerations has been proposed and mechanisms of monotowns state support have been analyzed.
\end{abstract}

Keywords: monotown, enterprise forming monotown, relations in labor market, monopsony, urban agglomerations

\section{Introduction}

Reformation of economic and administrative relations in the Republic of Kazakhstan caused shifts in the system of regional economy management. It in turn caused forming and maturing of regional self-dependence and local self-government. However, underdevelopment of mechanisms of management has deepened problems caused by social and economic inequalities of different regions of the republic.

So it is necessary to undertake and realize promptly the complex of measures aimed on drawing of investments to monotowns, on realization of investment projects in regions, on development of small and middle-size business (SMB), on loosing economic dependency of monotowns on economic results of enterprises forming these towns.

Factory towns or monotowns in the Republic of Kazakhstan are towns with population up to 200 thousand where most able-bodied population works in one or more enterprises that form such towns. As usual these enterprises are specialized in one core business and most economic and social processes in town depend on the results of this business.

In the Program of development of factory towns for 2012-2020 the following criterion of monotowns are used: one or more enterprises forming monotown with industrial output more than $20 \%$ of town economic output and more than $20 \%$ of able-bodied population employed in these enterprises (On approval of The Program of development of factory towns for 2012-2020 Government of the Republic of Kazakhstan Order \# 623 dated May 25, 2012).

The problems of monotowns and perspectives of their survival in future have pressing character now. Monotowns are typical for most developed countries of the world and according to general experience most of them have the same problems irrespective of country and region. Problem of monotows is now the most pressing one in Kazakhstan due to vast territory of the republic. Solving it may decrease negative effects of financial crisis and promote development of the republic in future.

Considering urgent character of the problem of monotowns in 2012 the President of the Republic of Kazakhstan N. A. Nazarbaev made an order to government to work out integral program of development of monotowns that should provide for measures aimed on diversification of each certain urban economy and development of social sphere of monotowns (On measures of realization of The Message of the President to the people of Kazakhstan dated January 27, 2012 (Social and economic modernization - the main vector of development of the Republic of 
Kazakhstan) Decree of the President of the Republic of Kazakhstan \# 261 dated January 30, 2012).

There are now 27 towns in Kazakhstan that are officially considered factory towns with total population more than 1.5 million. It is more that $16 \%$ of urban population of Kazakhstan. According to expert evaluation, enterprises that forms factory towns fully operate in 19 towns, partially operate in 5 towns and does not operate in 3 towns (JSC Mining and processing complex in Tekeli, branch of corporation (PK Uoyzhpolimetall) in Kentay and bankrupt JSC(Plant of non-organic materials) in Serebryansk). Enterprises that form monotowns belong mainly to processing industry: coal mining (4 monotowns), oil and gas production ( 3 monotowns), iron ore extraction (10 monotowns) (Shedenov \& Myrzaliev, 2013).

In most cases economic problems of monotowns are caused by low extent of diversification of economy, lack of perspectives of further development of enterprises that forms these towns, workforce and budget of monotowns dependency on economic results of enterprises.

It results in numerous social problems such as high rate of unemployment, low income of population and poor standards of living, outflow of population, high probability of social tension. Besides shutdown or threat of shutdown of main enterprises, depletion of mineral base of main extracting enterprises, low competitiveness of production, high dependency of population on tax deductions of enterprises, decrease of tax are also possible.

As since the period of the USSR monotowns were founded on the base of enterprises of mining industry, serious environmental problems are also typical for these towns. For example, the river Nura in Temirtau has been polluted with mercury, these is no special solid waste ground in Zyrianovsk and after flooding of mine the town is under-flooded with underground water.

Opinion that development of factory towns results from mistakes in planning, lack of investments and so on has passed in professional literature many times. But factory towns have been forming not onlyfor economic reasons. According to some researchers, factory type of towns is typical feature of most small and middle-sized towns because as in the system of urban settlements only a few may be big cities, all small and middle-sized towns cannot be multi-sectoral (Kolesnikov, Antonov, \& Ivanova, 2007). The fact that monotowns have been typical for a number of counties for a long period proves objective character of this phenomenon that is caused by specific character of economic and spatial development of territories (Ushakov, 2008).

Stable development of monotowns may be achieved by regulation of distributed structure of all the complex of town's subsystems - social and economic, environmental, institutional. Social and economic factor of stable development is fundamental and basic because it is directly related to growth of social and managerial resources activity that results in stirring up of aggregate potential of constructive groups of population that understand the importance of participation in solving problems of monotowns.

The main aim of solving the problem of monotowns is sustainable social and economic development of these towns in medium-term and long-term perspective. The main results are the following:

1. Optimization of monotowns' economy that depends on industrial output of stable operating enterprises;

2. Diversification of economy including development of SMB;

3. Development of optimal employment pattern of population of monotowns;

4. Distribution of manpower resources by improvement of labor mobility oriented on economic growth;

5. Support of social and technological infrastructure of monotowns considering optimal population size (Ryakhovskaya, 2014).

According to some experts, classification of monotowns by economic potential (high, medium and low) and differentiation of measures in accordance with this classification may give mechanism of solving the problem. Diversification of economy, followed by development of SMB; development of manpower for realization of innovative projects; support for social and technological infrastructure of monotowns considering optimal population size may be the measures for monotowns with high and medium potential. Support for employment of population by development of SMB; distribution of manpower by increase of manpower mobility in directions of economic growth; support for social and technological infrastructure on minimal required level may be measures for towns with low potential (Bektasova, 2014).

All the above shows that problems of monotowns may be considered as problems of state importance by scope and social and economic importance. 


\section{Methods}

One of main focal points of the problem of monotowns is the sphere of social and labor relations in labor market. Research in this sphere is urgent due to the fact that in the situation of economic crisis problems in labor market of monotowns may give impulse for social explosion because manifestations of crisis in monotowns touch each family living in them.

It is an open secret that monotowns have leading positions in unemployment. According to Vice-Minister of Regional Development Kairbek Uskenbaev, figures of unemployment comparing with average in the republic are high in towns Arkalyk, Kentau and Aksu. In most monotowns more than one third of able-bodied population belongs to the category of self-occupied. Towns Karatau, Arkalyk, Zhitikara, Zhanatas, Kulsary has high level of self-occupied population (Efimova, 2011).

So the problem of labor market in medium monotowns of the Republic of Kazakhstan is getting more and more pressing character.

In general two functions are being realized in relations in labor market: economic and social. The essence of economic function is provisioning of population with economically grounded jobs that allows workers to realize their interest, achieve high productivity and get worthy reward for it. The essence of social function is the fact that engagement of population is oriented both on solving economic tasks and development of human potential in general.

Social and economic nature of human resources is one of the basic economic resources and main factor promoting economic development of society. In monotowns relations in labor market play a special role. That is why research of labor market of monotowns is leading directions in efforts to improve sustainability of such towns.

Relations in labor market of monotowns are interrelated interaction of subjects that is realized in the process of work and aimed on regulation of specific features of labor (Ivanov \& Leontieva, 2012).

Hired labor, enterprises forming monotowns, authorities are subjects of relations in labor market of monotowns. Diverse dimensions of labor activity of labor, enterprises and other organizations in monotowns are object of relations in labor market.

All components of relations in labor market of monotowns may be grouped in subsystems:

1. Institutional subsystem that includes social responsibility of enterprises and social partnership;

2. Technical subsystem that includes organization of social and labor relations and productivity of labor;

3. Social subsystem that includes dimensions of employment and reward.

According to the model of labor market developed by C. Lead beater, labor market of monotowns may be divided into the following segments:

- (Core), or employment by enterprise forming a monotown that has stable character and that is valuable in favorable conditions in market in full-time mode;

- (Periphery), or employment by other enterprises of a monotown and in small business. Contract form of engagement, part-time, seasonal or remote types of engagement are typical for this segment;

- Unemployed (Mamzina, 2011).

Main specific of relations in labor market of monotowns is that the sphere of social and labor relations in core enterprise (relations between a worker and employer in using employee's capability to work) may be identified (consider completely the same) to sphere of relations in labor market of monotown as a whole.

It is basic difference of monotowns and municipal entity that has diversified structure of economy where relations in labor market are the total of all social and labor relations in many enterprises.

So relation in labor market of monotowns should be viewed taking into consideration social and labor relations in enterprise forming monotown because they effect development of monotown in general.

\section{Results}

So basing on analysis of scientific literature, documents, results of survey of social and labor relations in labor market of monotown Satpaev (Karaganda region) and Zhanaozen (Mangistay region) we made attempt to analyze social and labor relations in labor market of monotowns.

Staffs of JCS (Kazakhmys Corporation) (Satpaev) (mines, mining trust, concentrating mill) and manufacturing 
branch (Ozenmunaigas) of corporation (Razvedka Dobycha (KazMunaiGaz) (Zhanaozen). 375 workers took part in survey. Analysis of the results of survey allows to make the following conclusion.

Workers are interested in non-hazardous production and that provide worthy terms of work.

Interests of monotowns in general are stable functioning of enterprise, environmental safety of manufacturing and worthy living standards of population.

Analysis of labor market of monotowns allows making conclusion that this market is monopsony in its nature (i.e. it is a market with only one employer) unlike competitive labor market.

Main characteristics of labor market of monotowns that allows qualifying labor market of monotown as monopsony are the following:

Firstly, significant number of qualified workers interacts in labor market of monotown with one big monopsonic company or group of companies that act as a single employer (i.e. enterprise or group of interconnected enterprises);

Secondly, this enterprise (group of enterprises) hires greatest share of total number of specialists with a certain qualification;

Thirdly, labor type used in enterprise is characterized by low mobility;

Fourthly, monopsonic company alone sets wage level and workers are forced either to accept it or try to find other work.

There are other employers in labor market of monotowns but their effect on this market is low comparing with enterprise that forms factory town.

One should note that employment and wage level in monopsony is always lower that employment and wage level in competitive labor market.

So monopsony in labor market of monotowns is characterized by the fact that monopsonic company maximizes its revenue by attracting lower number of workers for lower salary comparing with competitive labor market. So labor market of monotowns is less flexible in reacting on changes in external labor market that relate to wage level.

Besides, enterprise provides work places for most part of population of monotown and set wage level for workers of enterprise, it plays dominating role in the process of social development of monotown because it invests a part of its income in town's infrastructure to support its worthy level that leads to social stability in the town. Most enterprises are owners or co-owners of critically important for monotown companies and bodies of social and community facilities that are not controlled by municipal bodies. This situation requires regular monitoring of the state of social responsibility of an enterprise that forms monotowns.

Results of research have also showed that high level of unemployment is one of the most important indicators of labor market of monotowns. The main reasons of unemployment are the following:

- Economic (type of industry, level of its development, general state of the market, level of competition in the market, profitability of production of enterprise, state of capital of enterprise and so on);

- Demographic (manpower strength, sex and age distribution, manpower ageing);

- Geographic (distance from leading markets, urban agglomerations);

- External (state of global resource markets).

Additional growth of unemployment level in monotowns during economic crisis is caused by narrow channel of labor utilization, dependence of situation in labor market on the state of enterprise because shrinking of production of enterprise causes shrinking of operations of all infrastructure of monotown (community facilities, power supple, etc.) and as a result cutting jobs.

Deterioration of urban environment together with lowering of salaries and unemployment causes deterioration of social mood and leads to growth of the number of people with drug addiction, alcoholism and a crime wave in monotowns.

So main factors in development of relations in labor market of monotowns are activity of enterprise that forms monotown and its relationships with other subjects of these relations because it is:

- Jobs providing enterprise, because most part of population of monotown is hired by it,

- Budget forming enterprise, because local budget is formed out of income that is in part created by salary that is 
paid by enterprise,

- Society forming enterprise, because it is the source of different social goods and at the same time creates unique urban subculture that depends on activity of enterprise,

- Image making enterprise, because its status and position define prestige of enterprise related activity.

According to the result of survey, additional specific of relations in labor market of monotowns is defined by the fact that self-occupation in these towns is low. So small business plays insignificant role in forming such basic social and economic indicators of monotowns as total employment, total revenue generated by production and service, tax deduction volume to local budgets.

However development of SMB may be universal instrument of reformation of economic and social spheres of monotowns that allows providing economic growth, growth of competitiveness of municipal entity, creating new jobs. Development of small and middle-size business leads to development of competition, to creation of unique innovative environment, strengthening of reliability of local society and as a result may play the role of main tool of decreasing of negative problems of monotowns.

Analysis of changes in status of different social groups in labor market of monotowns has shown that financial crisis caused significant growth of possibility to lose work and lowering the possibility to be hired. As a result number of unemployed that have no possibility to get hired for a long time has grown that caused long-term unemployment and growth of social tension. Stagnant unemployment has a number of negative consequences. It not only has negative effect of the level of income of a certain worker, local and regional budget and economy as a whole, but also causes loss of human capital, growth of the number of people below the poverty line.

\section{Discussion}

One of the main problems in development of monotowns is a low rate of creation of economic and social terms of innovations deployment, low business activity of population, low efficiency of local self-government that depends on enterprise that forms monotown as well as low readiness of majority of population to change of place of residence, pass training or change profession. Main factors that cause lowering the rate of economic growth in monotowns are irrelevance of material and managerial capabilities of local self-government, lowering of municipal income, high level of corruption. Still it's worth noticing that monotowns have high potential of further development due to high concentration of human capital with high professional, creative and education level; developed transport and communication infrastructure, concentration of trained workforce. The main measure aimed on lowering tension in labor market of monotowns always was moving of population to regions with deficit of the workforce.

Development of urban agglomerations may be an alternative to moving workforce cut by unprofitable enterprises. It is effective strategy that allows widen the sphere of employment, decrease unemployment, lead to development of infrastructure and business activity that may help monotowns to promote economic growth.

Positive economic effect of urban agglomerations has been proved by numerous researches. Manufacturing facilities placed close to each other are more efficient that isolated companies. This fact is especially important for Kazakhstan due to irregular social and economic development of different territories. One of the aspects of this irregularity is economic backwardness of monotowns (Roschina, Dyatlova, \& Roschina, 2012, pp. 54-63).

According to some researchers, monotowns may contribute to economic growth of focal points of concentration of manpower and material resources. So the strategy of drawing monotowns to focal points of urban agglomerations by forming transport and social infrastructure, joining resources that form factors of production, lowering costs and in perspective growth of educational and qualification level of population may result in solving the problem of lack of resources and economic backwardness (Ispulova, 2010).

In modern scientific researches urban agglomerations are considered as compactly located mainly urban settlements that are joined into complex multi-unit system that is characterized by intensity of production, communication and cultural links. Urban agglomerations may be divided into two types: mono-centric and poly-centric. The core of agglomerations of the first group is big city and several urban agglomerations of different sized are the base of second group (Ivanova \& Vyalshina, 2012).

Agglomeration process results in creation of new jobs, growth of demand in local labor market, growth of employment in small and medium towns. With development of periphery, pressure on infrastructure of big cities decreases limiting over-population of these cities. Development of small and medium-sized towns and diversification of their productive and social activity is followed by growth of their impact on neighboring territories. 
Interrelationship and interconnection in the scope of urban agglomeration include also movements of population of agglomeration related to work and education, visiting entertaining and recreation centers, hospitals. It presupposes organization of stable transportation facilities. Production interactions of different companies located in the boundaries of urban agglomeration are also important that leads to development of cargo transportation and relevant transportation corridors.

Other important advantages of today urban agglomerations in the context of this research are labor relationships that causes forming additional flows of push-pull migration in case workers of one company located in one town live in the other. Integrity of labor market of monotowns may be strengthened and added by development of integral housing market that forms additional (development resource) i.e. human capital comprised of qualified staff, new projects and technologies.

So, forming and development of urban agglomerations in solving problems of monotowns is complicated, multi-faceted process that required effective managerial decisions.

State support is necessary to solve the problem of diversification of economic and productive activity, market structure and revenue sources in monotowns.

Instruments of state support of monotowns depend directly of the situation and main type of problems for each monotown.

If operation of enterprise that forms monotows is not significantly disrupted and its situation is relatively stable (for example, oil and gas extracting enterprises and nuclear power plants) it requires monitoring to foresee and preventing possible deterioration in future.

If the main problem of enterprise is temporary difficulties with distribution of production due to temporary degradation of sales and in growing the volume of liabilities to suppliers (for example, in metallurgy, mechanical engineering) it required short-term support by loan financing against security or with support of state banks or by forming government order followed by measures aimed on support of employment of population of monotowns.

If main problems of enterprise that forms monotown are low productivity, significant worn out of main assets, low competitiveness of production, measures aimed of modernization of manufacturing facilities should be undertaken. These measures may be mutual financing of modernization projects by regions and banks with state control, provisioning of grants and in emergency cases state interference may be required up to denationalization of an enterprise.

If further operation of an enterprise is obviously economically unreasonable due to fully obsolete technologies, remoteness of main markets main instrument of state support should be assistance in diversification of production with further retraining of staff. Special attention should be paid to strategic planning of monotown development that presupposes working out diversification scenario; measures aimed on development of other industries such as agriculture, food industry, tourism. Programs of employment support and population migration are problems of special attention combined with state support of SMB.

\section{Conclusion}

In the current state of development forming of urban agglomerations is a reflection of logic processes of regional development of Kazakhstan that provides forming new (growth points), uniformity of territorial economic development, complex development of infrastructure objects. It results in creation of new jobs, growth of demand in local labor markets, growth of employment level.

International experience has proved that development of urban agglomerations has positive effect due to creation of new jobs, growth of demand for workforce that results from modernization of enterprises the forms a monotown and deepening of intra-agglomeration relations that leads to such positive social and economic results as decrease of unemployment, increase of the standards of living, diversification of employment structure and revenue sources.

To conclude with, carrying out effective state policy aimed on support of enterprises that form monotowns and employment in general is necessary condition of overcoming numerous problems of monotowns. Effective use ofinstruments of economic support and employment support of monotowns by state has positive effect and will lead to sustainable development, increase of living standards, growth of income and high employment level. It is socially oriented approach aimed on reproduction of potential of monotowns by increase of living and working standards and leveling of negative effects of unemployment. 


\section{References}

Bektasova, A. (2014, January 31). Accents of monotowns. Retrieved from http://www.bnews.kz

Efimova, E. A. (2011). The labor market of monotowns: State and perspectives. Prostranstvennaya Economika, (1).

Ispulova, S. N. (2010). Social and labor relations in the labor market mainstays: Problems and prospects. Vestnik $B S U, 4$.

Ivanov, S. A., \& Leontieva, A. N. (2012). Specific of development and usage of human capital in monotowns of Russia. Economika I Upravlenie, 11(85).

Ivanova, N. A., \& Vyalshina, A. A. (2012). Problems of labor market of monotowns under economic crisis. Theory and practice of social development, 4.

Kolesnikov, A. I., Antonov, G. D., \& Ivanova, O. P. (2007). Development of monotowns and social responsibility of an enterprise. Moscow, Nauka.

Mamzina, T. F. (2011). Development perspectives of small and medium-sized business in monotowns. Economy: vchera, segodnya, zavtra, 2.

On approval of The Program of development of factory towns for 2012-2020. Government of the Republic of Kazakhstan Order, 623.

On measures of realization of The Message of the President to the people of Kazakhstan dated January 27, 2012 (Social and economic modernization - the main vector of development of the Republic of Kazakhstan). Decree of the President of the Republic of Kazakhstan, 261.

Roschina, I. V., Dyatlova, N. A., \& Roschina, G. S. (2012). Sustainable development and stable safety of single-profile municipal entities. Tomsk State University Gerald, 4(20), 54-63.

Ryakhovskaya, A. N. (2014). The role of state programs in development of monotowns. Monography. Moscow, Publishing house (Magister), INFRA-M.

Shedenov, U. K., \& Myrzaliev, B. S. (2013). Problems of development of monotowns of Kazakhstan. Kazakh Scientific University Gerald, (5).

Ushakov, V. A. (2008). Specifics of manifestation of phenomenon of city single-functionality. Chinovnik, 108(53).

\section{Copyrights}

Copyright for this article is retained by the author(s), with first publication rights granted to the journal.

This is an open-access article distributed under the terms and conditions of the Creative Commons Attribution license (http://creativecommons.org/licenses/by/3.0/). 